\title{
Erratum to: Kinetic Characterization of Tyrosinase-catalyzed Oxidation of Four Polyphenols
}

\author{
Wan-yu LIU ${ }^{1}$, Cong-ming ZOU², Jian-hua HU¹ ${ }^{1}$ Zi-jun XU ${ }^{1}$, Lu-qin $\mathrm{SI}^{1}$, Jun-jun LIU1 ${ }^{1}$, Jian-geng HUANG ${ }^{1}$ \\ ${ }^{1}$ School of Pharmacy, Tongji Medical College, Huazhong University of Science and Technology, Wuhan 430030, China \\ ${ }^{2} Y$ unnan Academy of Tobacco Agricultural Sciences, Kunming 650021, China
}

(C) Wan-yu LIU, Cong-ming ZOU, Jian-hua HU, Zi-jun XU, Lu-qin SI, Jun-jun LIU, Jian-geng HUANG 2020

\author{
Current Medical Science \\ DOI https://doi.org/10.1007/s11596-020-2186-0 \\ 40(2):239-248,2020
}

\begin{abstract}
The article "Kinetic Characterization of Tyrosinase-catalyzed Oxidation of Four Polyphenols", written by Wan-yu LIU, Congming ZOU, Jian-hua HU, Zi-jun XU, Lu-qin SI, Jun-jun LIU, Jian-geng HUANG, was originally published electronically on the publisher's internet portal on May 2020 without open access. With the author(s)' decision to opt for Open Choice, the copyright of the article is changed to (C) The Author(s) 2020 and the article is forthwith distributed under a Creative Commons Attribution 4.0 International License (https://creativecommons.org/licenses/by/4.0/), which permits use, sharing, adaptation, distribution and reproduction in any medium or format, as long as you give appropriate credit to the original author(s) and the source, provide a link to the Creative Commons license, and indicate if changes were made.
\end{abstract}

The original article has been corrected.

Corresponding authors: Jun-jun LIU, Jian-geng HUANG

The online version of the original article can be found at https://doi.org/10.1007/s11596-020-2186-0 